\title{
Characteristics of Prostate-derived Growth Factors for Cells of the Osteoblast Phenotype
}

\author{
Michael Koutsilieris, Shafaat A. Rabbani, Hugh P. J. Bennett, and David Goltzman \\ Departments of Medicine, McGill University and Royal Victoria Hospital, Montreal, Canada H3A 1 A1
}

\begin{abstract}
We examined the characteristics of mitogens extracted from human benign prostatic hyperplasia and prostatic adenocarcinoma tissue. Although mitogens for fetal rat skin fibroblasts as well as for rat calvarial osteoblasts and osterosarcoma cells were found, distinct entities that acted selectively in cells of the osteoblast phenotype could be obtained by sequential reversephase high performance liquid chromatography. Two peptides with apparent molecular weights of 10,000 and 13,000 D were derived from hyperplastic tissue, whereas a single moiety of 10,000 D was obtained from malignant tissue. These entities increased cell numbers and alkaline phosphatase activity in osteoblastlike cells consistent with effects on both growth and differentiation. Prostatic peptides did not stimulate adenylate cyclase in osteosarcoma cells. Mitogenic activity selective for osteoblastlike cells was identified in postpubertal but not prepubertal normal prostate. The results demonstrate the existence of osteoblastic growth factors in prostatic tissue whose presence may accompany postpubertal development.
\end{abstract}

\section{Introduction}

Prostatic adenocarcinoma is virtually unique among malignancies with respect to its high association with osteoblastic metastases (1). Earlier reports (1-4) described the presence of mitogens for cells of the osteoblast phenotype and for fibroblasts in both benign prostatic hyperplasia and prostatic adenocarcinoma tissue or cells. We previously found that mitogens extracted from hyperplastic and neoplastic prostatic tissue were trypsin-sensitive (3) and acid stable (unpublished observations), and that activity selective for cells of the osteoblast phenotype was basic (unpublished observations) and could be enriched by hydrophobic chromatography (3). In the present study we have further examined the chromatographic characteristics of this material and assessed its effect on alkaline phosphatase activity, a parameter of osteoblast differentiation, and on adenylate cyclase activity in osteoblastlike cells. We also compared the mitogenic activity of hyperplastic and neoplastic prostatic tissues to that seen in normal and neoplastic nonprostatic tissues and to that present in normal preand postpubertal prostate.

Address correspondence and reprint requests to Dr. D. Goltzman, McGill University, Allan Research Building, Room 117, 1033 Pine Ave. West, Montreal, PQ Canada H2A 1 A1.

Received for publication 18 February 1987 and in revised form 20 May 1987.

J. Clin. Invest.

(C) The American Society for Clinical Investigation, Inc.

$0021-9738 / 87 / 10 / 0941 / 06 \$ 2.00$

Volume 80, October 1987, 941-946

\section{Methods}

Tissues. Five pools of human prostatic adenocarcinoma (CA), ${ }^{1}$ and seven human benign prostatic hyperplasia (BPH) tissue biopsies obtained at surgery were kept frozen at $-70^{\circ} \mathrm{C}$ until use. Gastric, colonic, and breast adenocarcinoma tissue were also obtained at the time of surgery and kept frozen at $-70^{\circ} \mathrm{C}$ until use. These tissues were removed from patients who had no evidence of skeletal metastases or hypercalcemia. Normal postpubertal prostate and normal kidney, seminal vesicles, and gastric tissue were obtained from a 24-yr-old car accident victim at autopsy performed $6 \mathrm{~h}$ after death. Normal prepubertal prostate was obtained from a 7-yr-old car accident victim at autopsy performed $3 \mathrm{~h}$ after demise of the patient. A specimen of lymphoma was obtained at surgery from a 5-yr-old male without skeletal metastases but with clinical and biochemical features characteristic of the syndrome of humoral hypercalcemia of malignancy as previously described (5).

The Leydig cell tumor (Rice H-500) that produces hypercalcemia in Fischer rats (6) was obtained from the E. G. and G. Mason Research Institute, Worcester, MA, through the courtesy of Dr. E. P. Anderson of the Breast Cancer Animal and Human Tumor Bank, National Cancer Institute, and was maintained by subcutaneous transplantation. After $\sim 14 \mathrm{~d}$ when serum calcium was $13-14 \mathrm{mg} / \mathrm{dl}$, tumors were removed, frozen, and kept at $-70^{\circ} \mathrm{C}$ for subsequent use.

Growth factors. Highly purified mouse epidermal growth factor (EGF) and bovine pituitary (basic) fibroblast growth factor (FGF) were from Sigma Chemical Co., St. Louis, MO. Platelet-derived growth factor (PDGF) was from Bethesda Research Laboratories, Gaithersburg, MD. Insulinlike growth factor (IGF) was a mixture of $67 \%$ IGF-I and 33\% IGF-II. The activity of this preparation was 7,000 ng-equivalents $/ \mathrm{ml}$ relative to an insulin standard in a radioreceptor bioassay and was kindly supplied by Drs. H. J. Guyda, C. Polychronakos, and B. I. Posner, McGill University, Montreal, Quebec, Canada.

Initial extraction procedures. Tumor tissue was extracted, as previously described $(3,7)$. Tissue was first homogenized at $0^{\circ} \mathrm{C}$ in acetone $(30 \mathrm{ml} / \mathrm{g})$. The insoluble precipitate was then homogenized in $n$-hexane $(30 \mathrm{ml} / \mathrm{g})$, and the insoluble material from this procedure was homogenzied again in acetone $(30 \mathrm{ml} / \mathrm{g})$. The dried and defatted residue was then extracted in a mixture $(40 \mathrm{ml} / \mathrm{g})$ of $1 \mathrm{M} \mathrm{HCl}$ containing $5 \%$ (vol/vol) formic acid, $1 \%(\mathrm{wt} / \mathrm{vol}) \mathrm{NaCl}$, and $1 \%$ (vol/vol) trifluoroacetic acid $\left(\mathrm{F}_{3} \mathrm{CCOOH}\right)$. This acidic medium was designed to maximize solubilization of peptides while precipitating high-molecular weight protein. The supernatant from this procedure was then passed through cartridges of octadecylsilyl (ODS)-silica $\left(\mathrm{C}_{18} \mathrm{SepPak}\right.$, Waters Associates, Mississauga, Ontario, Canada) which were washed with $0.1 \% \mathrm{~F}_{3} \mathrm{CCOOH}$ and eluted with $80 \%$ acetonitrile. One cartridge was used for each $0.75 \mathrm{~g}$ (wet weight) tissue extracted.

High-performance liquid chromatography (HPLC). Chromatography was performed on a Waters Associates HPLC system consisting of one $6000 \mathrm{~A}$ pump, one M-45 pump, and an M720 system controller. Column eluates were monitored for ultraviolet (UV) absorbance at 280,210 , or $214 \mathrm{~nm}$ using a variable wavelength flowthrough spectro-

1. Abbreviations used in this paper: $\mathrm{BPH}$, benign prostatic hyperplasia; CA, adenocarcinoma; EGF, epidermal growth factor; FGF, fibroblast growth factor; IGF, insulinlike growth factor; ODS, octadecylsilyl; PDGF, platelet-derived growth factor; PTH, parathyroid hormone. 
photometer (model M480, Waters Associates) and an M730 data module (Waters Associates). Aliquots were employed for bioassay.

Reverse-phase HPLC was performed, as previously described (3, 7), on $\mathrm{C}_{18} \mu$ Bondapak columns (Waters Associates). Samples for loading were diluted with $0.1 \% \mathrm{~F}_{3} \mathrm{CCOOH}$, and columns were developed over $60 \mathrm{~min}$ at a flow rate of $1.5 \mathrm{ml} / \mathrm{min}$ with linear gradients of acetonitrile containing $0.1 \% \mathrm{~F}_{3} \mathrm{CCOOH}$, as a counter ion.

Exclusion HPLC (8) was carried out on an I-125 gel permeation HPLC column (Waters Associates) connected in series with a Protein Pak 300-SW gel permeation column (Waters Associates), eluting at a flow rate of $1 \mathrm{ml} / \mathrm{min}$ with $40 \%$ aqueous acetonitrile containing $0.1 \%$ $\mathrm{F}_{3} \mathrm{CCOOH}$. Calibration was achieved by injection of a mixture of 0.5 $\mu \mathrm{g}$ of each of the following in $25 \mu \mathrm{l} 40 \%$ acetonitrile containing $0.1 \%$ $\mathrm{F}_{3} \mathrm{CCOOH}$ : bovine serum albumin (BSA; Sigma Chemical Co.), human growth hormone (kindly supplied by the National Institutes of Health, ribonuclease, aprotinin, (both from Boehringer Mannheim, Montreal, Quebec, Canada), and bovine $\beta$-MSH (extracted from bovine pituitary glands and purified in our laboratory).

Preparation of indicator cells. Osteoblastlike cells were isolated from 19-d-old Sprague-Dawley rat fetuses $(9,10)$. Frontal and parietal bones of fetal calvaria were incubated for $90 \mathrm{~min}$ at pH 7.4 in Hanks' balanced salt solution (HBSS) containing $2 \mathrm{mg}$ of crude collagenase per $\mathrm{ml}$ (70\% type I, 30\% type II; 140-160 U/mg; Sigma Chemical Co.). Cells released between 30 and 90 min of incubation were grown in primary culture in 24-well tissue culture plates (Linbro, Flow Laboratories, Hamden, CT $)\left(1.5 \times 10^{5}\right.$ cells per well) in RPMI 1640 medium (Gibco, Grand Island, NY) containing 5\% fetal bovine serum (Gibco) at $37^{\circ} \mathrm{C}$ in an atmosphere of $5 \% \mathrm{CO}_{2}$ and $95 \%$ air. These cells contained parathyroid hormone-responsive adenylate cyclase activity and $>85 \%$ of cells stained positively for alkaline phosphatase. Consequently these cells appeared to express the osteoblast phenotype. Fibroblasts were similarly isolated from the skin of 19-d-old rat fetuses by collagenase digestion for $90 \mathrm{~min}$ and were grown under the same conditions. The osteoblast-derived established osteosarcoma cell line (11), UMR 108, was grown in 24-well culture plates $\left(1.5 \times 10^{5}\right.$ cells per well) in RPMI 1640 medium containing $2 \%$ fetal bovine serum.

Bioassays. To assess stimulation of DNA synthesis (3), samples for bioassay were added to primary cultures $48 \mathrm{~h}$ after plating or to osteosarcoma cells $14 \mathrm{~h}$ after plating. Cultures were then incubated with RPMI 1640 medium containing 2-5\% fetal bovine serum. $22 \mathrm{~h}$ later 2 $\mu \mathrm{Ci}$ of $\left[{ }^{3} \mathrm{H}\right]$ thymidine (sp act, $50-80 \mathrm{Ci} / \mathrm{mmol}$; New England Nuclear, Boston, MA) were added to each well. After $2 \mathrm{~h}$ of incubation the medium was aspirated and the cells were washed twice with ice-cold HBSS and once with $1 \mathrm{ml}$ of cold $1.2 \mathrm{~N}$ perchloroacetic acid. The perchloroacetic acid-insoluble material was dissolved in $2 \mathrm{ml}$ of $0.6 \mathrm{~N}$ $\mathrm{NaOH}$ and ${ }^{3} \mathrm{H}$ radioactivity was then estimated by liquid scintillation spectrometry. To determine effects on cell proliferation, 1,3 , and $5 \mathrm{~d}$ after addition of samples for bioassay the number of cells per replicate culture was estimated by enzymatic dispersion ( $0.25 \%$ trypsin and 1 mM EDTA) and counting in a hemocytometer.

Alkaline phosphatase activity was measured in culture medium, or in cell extracts after a 24-h incubation with test factor, by the hydrolysis of p-nitrophenyl phosphate (Sigma Chemical Co.). An aliquot of the tissue culture medium was incubated with $8 \mathrm{mM}$ p-nitrophenyl phosphate in $0.5 \mathrm{M}$ 2-amino 2-methyl 1-propanol buffer for $30 \mathrm{~min}$ at $37^{\circ} \mathrm{C}$ and the $p$-nitrophenol liberated was measured in a spectrophotometer at a wavelength of $410 \mathrm{~nm}$. Alternatively, after washing, cells were freeze-thawed three times, the lysate scraped from each well with a rubber policeman, and aliquots incubated with phosphatase substrate (12). Alkaline phosphate activity was expressed as the amount of $p$-nitrophenol liberated in nanomoles per 30-min incubation per milliliter of medium or in micromoles per 60 -min incubation per milligram cell protein.

Adenylate cyclase assays were performed in cloned rat osteosarcoma cells (UMR 108) (13). At confluence, cells were incubated with 1 $\mu \mathrm{Ci}\left[2-{ }^{3} \mathrm{H}\right]$ adenine $(16 \mathrm{Ci} / \mathrm{mmol} ; 1 \mu \mathrm{Ci} / \mu \mathrm{l}$; New England Nuclear) for 2 $\mathrm{h}$ in $1 \mathrm{ml}$ culture medium per well. Immediately before addition of agents to be tested, the medium was aspirated from the wells, and the cells were washed twice with $1 \mathrm{ml} \mathrm{HBSS}$ to remove excess $\left[{ }^{3} \mathrm{H}\right] \mathrm{adenine}$. Tumor extracts or hormones were dried in a Speed-Vac concentrator (Savant Instruments, Hicksville, NY) before assay and then added to the cells in $0.5 \mathrm{ml} \mathrm{McCoy's} 5 \mathrm{~A}$ medium (Gibco) containing $0.1 \% \mathrm{BSA}$, $0.2 \mathrm{mM}$ 3-isobutyl-1-methylxanthine (Sigma Chemical Co.), and $10^{-6}$ M forskolin (Calbiochem-Behring Corp., La Jolla, CA). Bovine parathyroid hormone (PTH)-(1-84), used as a standard in the assay, was purchased from Bachem Co., Torrance, CA. After incubation at $22^{\circ} \mathrm{C}$ for $10 \mathrm{~min}$, the reaction was stopped by aspiration of the hormone-medium mixture and immediate addition of $0.5 \mathrm{ml}$ of $10 \%$ trichloroacetic acid. $\sim 3,000 \mathrm{cpm}$ of $\left[{ }^{14} \mathrm{C}\right] \mathrm{cAMP}(53.1 \mathrm{mCi} / \mathrm{mmol}$, New England Nuclear) were added in a carrier solution containing $5 \mathrm{mM}$ cAMP and $50 \mathrm{mM}$ ATP in a $100 \mu \mathrm{l} \mathrm{vol}$. [ $\left.{ }^{3} \mathrm{H}\right] \mathrm{cAMP}$ formed was isolated from the unneutralized acid samples by the method of Salomon et al. (14).

\section{Results}

Characterization of mitogenic activity in BPH and cancer extracts. Reverse-phase HPLC of extracts of BPH yielded mitogenic activity in all three indicator cells. However, two regions in which mitogenic activity was demonstrable in fetal rat calvarial cells and in osteosarcoma cells, but not in fibroblasts, could be observed (Fig. 1). In some prostatic extracts, only a single region of such bioactivity was found (Fig. 1). After rechromatography of these regions on reverse-phase HPLC, homogeneous UV peaks were obtained which retained activity in cells of the osteoblast phenotype but failed to stimulate activity in fibroblasts (Fig. 2). These peaks produced dose-dependent stimulation of $\left[{ }^{3} \mathrm{H}\right]$ thymidine incorporation (Fig. 3) and a

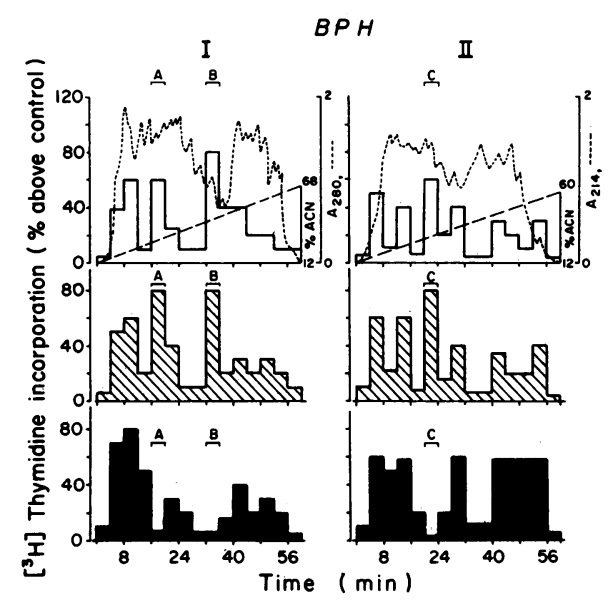

Figure 1. Reverse-phase HPLC profiles of ODS-silica extracts of two representative BPH specimens. The $C_{18} \mu$ Bondapak column was monitored for UV absorbance (- - ) and for bioactivity in assays measuring $\left[{ }^{3} \mathrm{H}\right]$ thymidine incorporation into UMR 108 osteosarcoma cells ( $\square$ ) fetal rat calvarial osteoblasts $(\mathbb{\nabla})$, and fetal rat skin fibroblasts (ם). Mitogenic activity ("[ $\left[{ }^{3} \mathrm{H}\right]$ thymidine incorporation") was determined, as described in the text, and expressed as $100 \times\left[{ }^{3} \mathrm{H}\right]-$ thymidine incorporation into cells incubated with extracts minus $\left[{ }^{3} \mathrm{H}\right]$ thymidine incorporation into cells incubated without extracts, divided by the latter ("\% above control"). Control levels of $\left[{ }^{3} \mathrm{H}\right]$ thymidine incorporation into osteosarcoma cells, osteoblasts, and fibroblasts were $28,248 \pm 1,120,11,921 \pm 628$, and $11,715 \pm 880 \mathrm{cpm}$ (mean \pm SEM of triplicate determinations), respectively. The column was eluted with a linear gradient $(--)$ of acetonitrile $(A C N)$ containing $0.1 \% \mathrm{~F}_{3} \mathrm{CCOOH}$, as described in the text. The pattern on the left $(I)$ was representative of that seen in three BPH biopsy pools examined, whereas that on the right (II) was representative of that seen in four pools. 


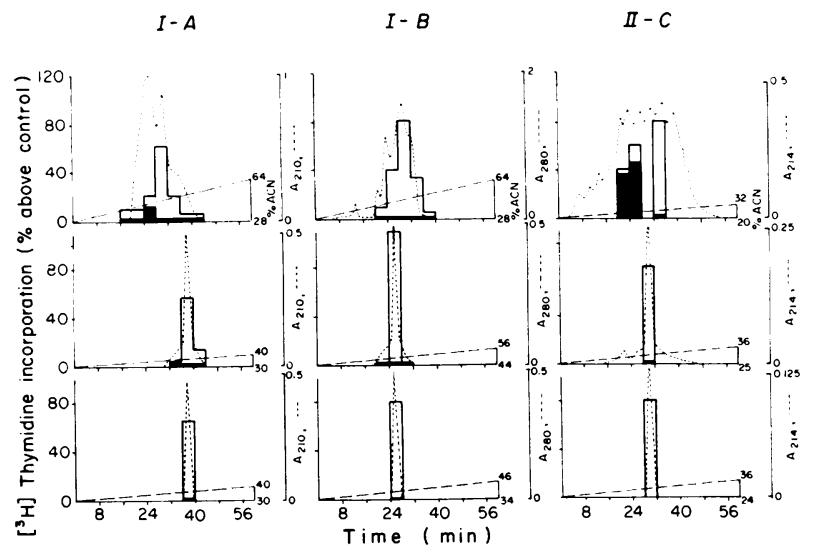

Figure 2. Reverse-phase HPLC profiles of further chromatography of regions $A$ and $B$ of prostate I from Fig. 1 (left three panels and middle three panels, respectively) and of further chromatography of region $C$ of prostate II from Fig. 1 (right three panels). The $\mathrm{C}_{18} \mu$ Bondpak columns were monitored for UV absorbance (- - -) and for bioactivity in assays measuring $\left[{ }^{3} \mathrm{H}\right]$ thymidine incorporation into UMR 108 osteosarcoma cells ( $\square$ ) and into fetal rat skin fibroblasts (๘). In each case, the eluted fraction with the major mitogenic activity for osteosarcoma cells was rechromatographed on the same column (vertical panels) until homogeneous UV profiles were obtained of all three species (bottom panels). Mitogenic activity was expressed as described in the legend to Fig. 1. Control levels of $\left[{ }^{3} \mathrm{H}\right]$ thymidine incorporation into osteosarcoma cells and fibroblasts, in the first (top panels), second (middle panels), and final (bottom panels) chromatographic steps were $12,125 \pm 215$ and $5,323 \pm 97,14,744 \pm 101$ and $4,847 \pm 56$, and $18,324 \pm 187$; and $7,475 \pm 91 \mathrm{cpm}$ (mean \pm SEM of triplicate determinations), respectively. Columns were eluted with linear gradients (- - ) of acetonitrile $(A C N)$ containing $0.1 \% \mathrm{~F}_{3} \mathrm{CCOOH}$ as described in the text.

dose-dependent increase in number (Fig. 4) of cells of the osteoblast phenotype. Additionally, graded doses of this material increased alkaline phosphatase activity in the osteoblastlike cells (Fig. 4).

Reverse-phase HPLC of prostatic cancer extracts also yielded activity mitogenic in the three indicator cells; however, a region of mitogenic activity selective for cells of the osteo-

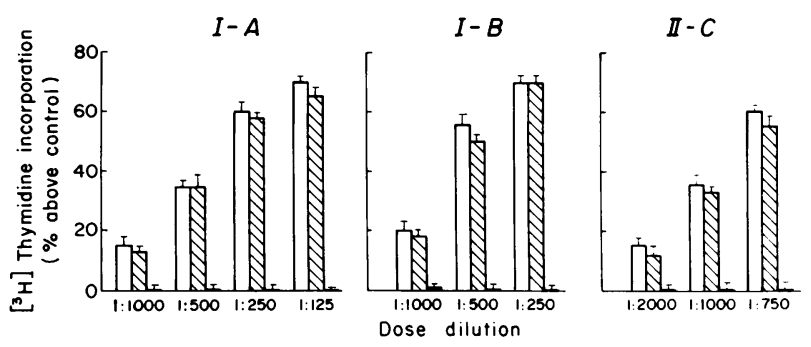

Figure 3. Effect of increasing concentrations of the peaks I-A, I-B, and II-C, obtained from the final HPLC steps shown in Fig. 2, on $\left[{ }^{3} \mathrm{H}\right]$ thymidine incorporation into osteosarcoma cells ( $\square$ ), fetal calvarial osteoblasts $(\mathbb{E})$, and fetal rat skin fibroblasts $(\boldsymbol{\square})$. A 1:1,000 dilution of I-A, I-B, and II-C represents $0.5 \mathrm{ng}$ of peptide. Mitogenic activity was expressed as described in the legend to Fig. 1. Control levels of $\left[{ }^{3} \mathrm{H}\right]$ thymidine incorporation into osteosarcoma cells, fetal rat calvarial osteoblasts, and fetal rat skin fibroblasts were 12,885 \pm 94 , $6,544 \pm 71$, and $5,347 \pm 82$ (mean \pm SEM of triplicate determinations), respectively.
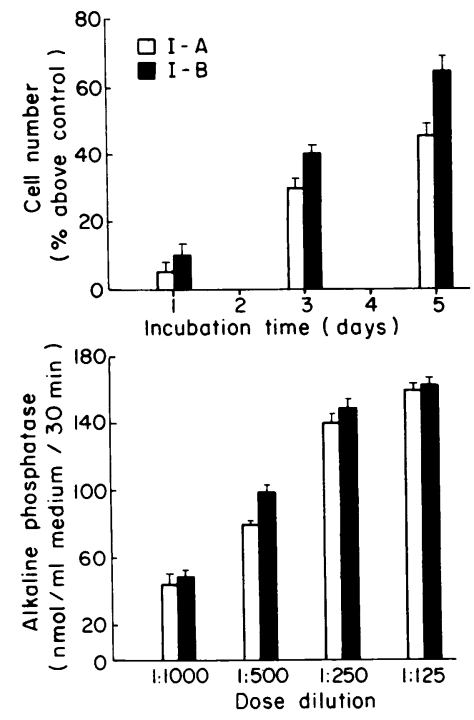

Figure 4. (Top panel) Effect of $1.0 \mathrm{ng} / \mathrm{ml}$ of peaks I-A and I-B, obtained from the final HPLC steps shown in Fig. 2, on numbers of osteosarcoma cells (UMR 108) after incubation for 1-5 d. (Lower panel) Effect of incubation, with osteosarcoma cells, of $1.0 \mathrm{ng} / \mathrm{ml}$ of peaks I-A and I-B, on alkaline phosphatase activity in cell medium. Similar results were obtained in studies examining alkaline phosphatase activity in cell extracts.

blast phenotype was seen as well with this tissue (Fig. 5). Further chromatography of this region also yielded a homgeneous UV peak (Fig. 6) which produced a dose-dependent increase in $\left[{ }^{3} \mathrm{H}\right]$ thymidine incorporation and in alkaline phosphatase activity (Fig. 7) in osteoblastlike cells.

To assess the responsiveness to growth factors of the fibroblast population we used, the mitogenic effect of the known growth factors EGF, PDGF, IGF, and FGF was tested. Each known mitogen produced dose-dependent stimulation of $\left[{ }^{3} \mathrm{H}\right]$ thymidine incorporation in the fibroblasts employed (Table I) attesting to the validity of the fibroblast population used and providing further evidence of the unique properties of the prostatic material that was selectively mitogenic in cells of the osteoblast phenotype.

When prostatic extracts were assayed in an adenylate cyclase assay in osteosarcoma cells, no stimulation above basal

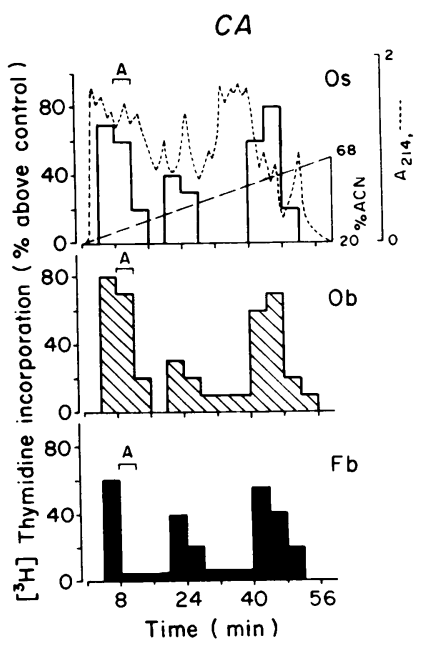

Figure 5. Reverse-phase HPLC profile of an ODS-silica extract of CA tissue. The $\mathrm{C}_{18} \mu$ Bondapak column was monitored for UV absorbance (- - -) and for bioactivity in assays measuring $\left[{ }^{3} \mathrm{H}\right]$ thymidine incorporation into UMR 108 osteosarcoma cells ( $\square$ ), fetal rat calvarial osteoblasts $(\mathbb{B})$, and fetal rat skin fibroblasts (घ). Mitogenic activity was expressed as described in the legend to Fig. 1. Control levels of $\left[{ }^{3} \mathrm{H}\right]$ thymidine incorporation into osteosarcoma cells, osteoblasts, and fibroblasts were $18,287 \pm 141$, $7,475 \pm 120$, and $6,671 \pm 48$

cpm (mean \pm SEM of triplicate determinations), respectively. The column was eluted with a linear gradient ( -- ) of acetonitrile $(A C N)$ containing $0.1 \% \mathrm{~F}_{3} \mathrm{CCOOH}$ as described in the text. This pattern was seen in four out of five prostatic cancer pools examined. In one pool, two regions of selective mitogenic activity for osteoblasts was detected as in pool I shown in Fig. 1. 


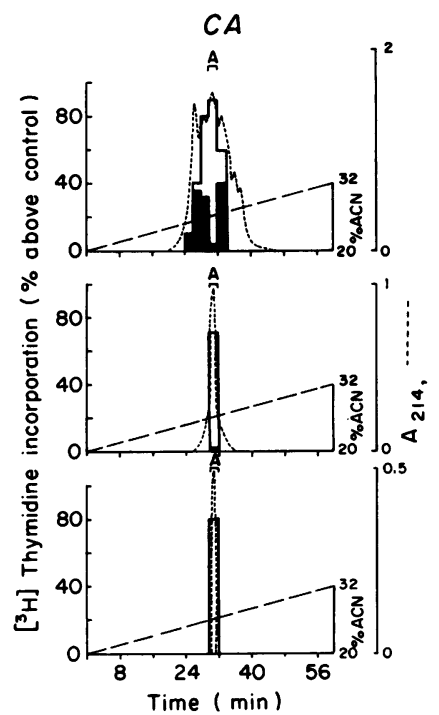

Figure 6. Reverse-phase HPLC profiles of further chromatography of region $A$ of $C A$ tissue from Fig. 1. The $\mathrm{C}_{18} \mu$ Bondapak column was monitored for UV absorbance (- - -) and for bioactivity in assays measuring $\left[{ }^{3} \mathrm{H}\right]$ thymidine incorporation into UMR 108 osteosarcoma cells ( $\square$ ) and into fetal rat skin fibroblasts ( $\square$ ). The major mitogenic activity for osteosarcoma cells was rechromatographed on the same column until a homogeneous UV profile was obtained. Mitogenic activity was expressed as described in the legend to Fig. 1. Control levels of $\left[{ }^{3} \mathrm{H}\right]-$ thymidine incorporation into osteosarcoma cells and fibro-

blasts were $16,375 \pm 117$ and $4,877 \pm 34 \mathrm{cpm}$ (mean \pm SEM of triplicate determinations), respectively. Columns were eluted with linear gradients $(---)$ of acetonitrile $(A C N)$ containing $0.1 \% \mathrm{~F}_{3} \mathrm{CCOOH}$, as described in the text.

was observed although PTH and extracts of cancers associated with hypercalcemia were stimulatory (Table II).

The UV peaks, obtained from sequential reverse-phase HPLC, appeared homogenous by gel permeation HPLC (Fig. 8). The earlier eluting peak, I-A, extracted from BPH tissue had an apparent 10,000 mol wt whereas the later eluting peak, I-B, had an apparent 13,000 mol wt. The material, II-C, obtained from a specimen of BPH from which only a single selective bioactive peak could be extracted, had an apparent $13,000 \mathrm{~mol}$ wt. The peak obtained from prostatic cancer tissue eluted with an apparent $10,000 \mathrm{~mol}$ wt.

Characterization of mitogenic activity in control tissues and normal prostate. Although mitogenic activity for all three indicator cells could be extracted from malignant gastric, colonic, and breast tissue (collected and stored in a manner identical to that of prostatic hyperplastic and malignant tissue) no activity selective for osteoblastlike cells could be resolved by reverse-phase HPLC analysis from these nonprostatic tissues (Fig. 9).

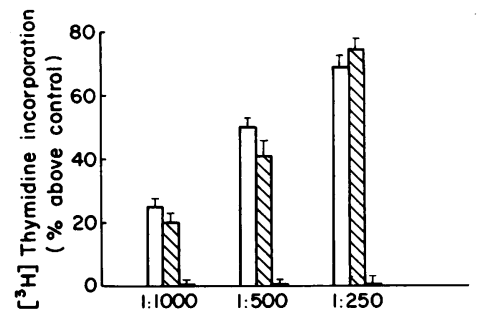

Figure 7. (Top panel) Effect of increasing concentrations of the peak obtained from the final HPL step shown in Fig. 6 on $\left[{ }^{3} \mathrm{H}\right]$ thymidine incorporation into osteosarcoma cells ( $\square$ ) fetal rat calvarial osteoblasts (ष), and fetal rat skin fibroblasts (a). A

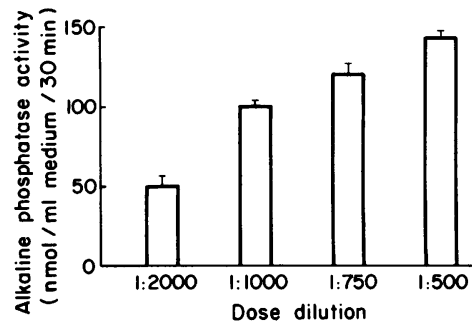

1:1,000 dilution represents $0.8 \mathrm{ng}$ of peptide. Mitogenic activity was expressed as described in the legend to Fig. 1. Control levels of $\left[{ }^{3} \mathrm{H}\right]$ thymidine incorporation into osteosarcoma cells, fetal rat calvarial osteoblasts, and fetal rat skin fibroblasts were

$17,366 \pm 148,8,281 \pm 104$, and $6,971 \pm 38$ (mean \pm SEM of triplicate determinations), respectively. (Bottom panel) Effect of incubation, with osteosarcoma cells, of the peak obtained from the final HPLC step shown in Fig. 6 on alkaline phosphatase activity in cell medium. Similar results were obtained in studies examining alkaline phosphatase activity in cell extracts.

Similarly, no mitogenic activity, selective for cells of the osteoblast phenotype, could be obtained by analysis of extracts of normal kidney, seminal vesicles, or stomach (Fig. 10). However when normal adult prostatic tissue collected and handled in an identical manner was examined, a single region of activity selectively mitogenic for cells of the osteoblast phenotype was observed (Fig. 11). This activity was not seen after chromatograhy of extracts of normal prepubertal prostate, although eluates active in all three cell types were obtained.

\section{Discussion}

Initial interest in the presence within prostatic tissue of growth factors for osteoblasts arose from the very high frequency, relative to other neoplasms, with which prostatic adenocarcinomas are associated with osteogenic metastases (1). Subsequent work indeed identified osteoblast mitogens in extracts of human prostatic cancer tissue (1-3) and in one study (4) messenger RNA extracted from a human prostatic cancer cell line

Table I. Effects of IGF, EGF, FGF, and PDGF on Tritiated Thymidine Incorporation in Skin Fibroblasts

\begin{tabular}{|c|c|c|c|c|c|c|c|}
\hline \multicolumn{2}{|l|}{ IGF } & \multicolumn{2}{|l|}{ EGF } & \multicolumn{2}{|l|}{ FGF } & \multicolumn{2}{|l|}{ PDGF } \\
\hline Concentration * & Response ${ }^{t}$ & Concentration & Response & Concentration & Response & Concentration & Response \\
\hline 10 & $28 \pm 3$ & 0.5 & $40 \pm 5$ & 0.5 & $30 \pm 5$ & 20 & $45 \pm 2$ \\
\hline 50 & $60 \pm 1$ & 1.0 & $65 \pm 3$ & 1.0 & $38 \pm 2$ & 200 & $70 \pm 5$ \\
\hline 80 & $69 \pm 2$ & 100 & $80 \pm 4$ & 10 & $80 \pm 3$ & 1,000 & $65 \pm 4$ \\
\hline 100 & $70 \pm 3$ & 1,000 & $75 \pm 2$ & 100 & $80 \pm 5$ & - & - \\
\hline
\end{tabular}

* Concentrations of growth factors are expressed in $\mathrm{ng} / \mathrm{ml} . \quad{ }^{\ddagger}$ Responses are $100 \times\left[{ }^{3} \mathrm{H}\right]$ thymidine incorporation into cells incubated with growth factors minus $\left[{ }^{3} \mathrm{H}\right]$ thymidine incorporation into cells incubated without growth factors, divided by the latter ("\% above control") and are expressed as mean \pm SEM of triplicate determinations. All values shown were significantly above control levels at $P<0.05$ as determined by Student's $t$ test. Control levels of $\left[{ }^{3} \mathrm{H}\right]$ thymidine incorporation into fibroblasts were $3,609 \pm 24 \mathrm{cpm}$. 
Table II. Effects of Extracts of Prostatic Tissue and of Malignancies Associated with Hypercalcemia on Adenylate Cyclase Activity

\begin{tabular}{lcl}
\hline Sample* & $\begin{array}{l}\text { Adenylate } \\
\text { cyclase activity }\end{array}$ & $P$ value $^{*}$ \\
\hline Basal & $1,473 \pm 53$ & - \\
BPH & $1,516 \pm 25$ & NS \\
CA & $1,560 \pm 80$ & NS \\
Lymphoma & $3,200 \pm 75$ & $<0.01$ \\
Leydig cell tumor & $3,900 \pm 45$ & $<0.01$ \\
PTH & $11,341 \pm 435$ & $<0.01$ \\
\hline
\end{tabular}

* Tissue samples ( $100 \mu \mathrm{g}$ of Lowry protein per sample) were assayed after extraction on cartridges of ODS-silica. PTH was added at a maximally stimulating concentration of $10^{-6} \mathrm{M}$.

₹ Adenylate cyclase activity was determined in UMR 108 osteosarcoma cells as described in Methods and expressed as [ $\left.{ }^{3} \mathrm{H}\right] \mathrm{cAMP}$ per culture plate per $10 \mathrm{~min}$ in counts per minute. Each value is the mean $\pm \mathrm{SD}$ of triplicate determinations.

\$Statistical significance determined by Student's $t$ test.

and microinjected into Xenopus oocytes directed the synthesis of mitogenic and stimulatory material for osteoblastlike cells. Moreover, mitogens active in both osteoblastlike cells and fibroblasts have been identified in extracts of human benign prostatic hyperplasia tissue as well as in malignant tissue. We previously demonstrated in such extracts that mitogens with the characteristics of basic peptides act preferentially on osteoblastlike cells (3). In the present study we have employed two cells of the osteoblast phenotype, one obtained from pri-

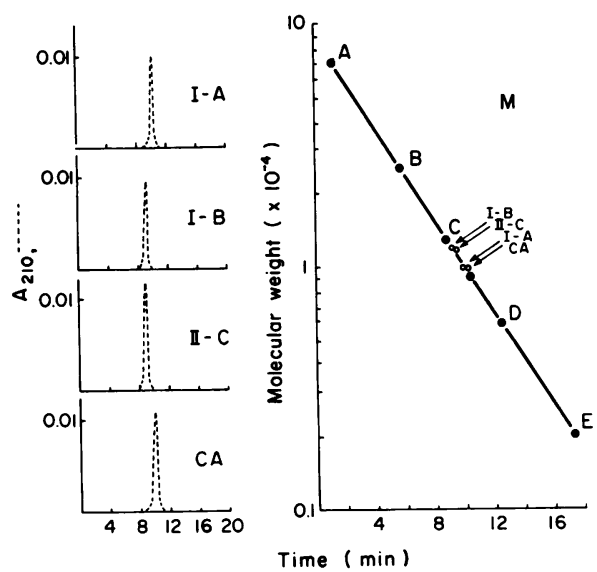

Figure 8. Gel permeation HPLC of material from BPH and prostatic CA tissue after reverse-phase HPLC. Shown in the panels labeled $I-A, I-B$, and $I I-C$ are the UV profiles of aliquots of bioactive peaks from the final step (bottom panels) of Fig. 2. Shown in the panel labeled $C A$ is the UV profile of an aliquot of the prostatic CA peptide from the final step (bottom panel) of Fig. 6. HPLC was performed as described in Methods. The columns (Waters I-125 and Waters Protein Pak 300-SW connected in series) were monitored for UV absorbance at $210 \mathrm{~nm}(---)$. Calibration $(M)$ was performed with BSA $(A)$, human growth hormone $(B)$, ribonuclease $(C)$, aprotinin $(D)$, and bovine $\beta$-MSH $(E)$. The molecular weight of peaks I-A, I-B, II-C, and CA were estimated using the retention time of standards $A-E$.

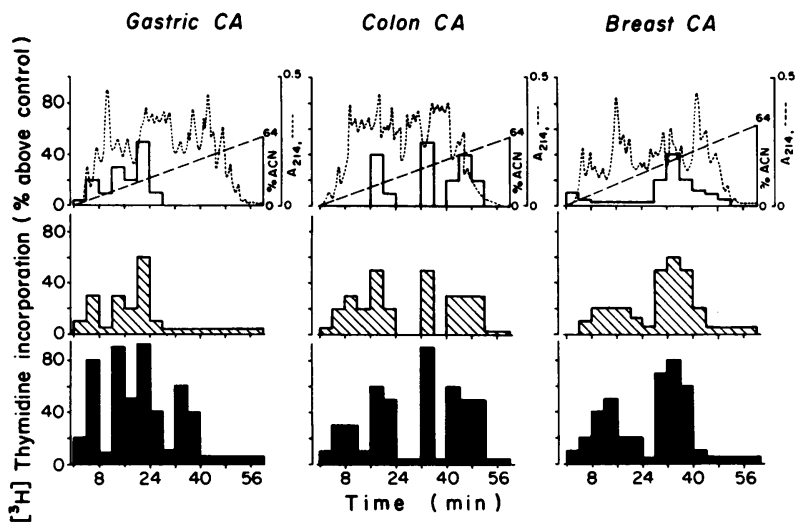

Figure 9. Reverse-phase HPLC profiles of ODS-silica extracts of gastric, colon and breast carcinomas (CA). The $\mathrm{C}_{18} \mu$ Bondapak columns were monitored for UV absorbance (- - ) and for bioactivity in assays measuring $\left[{ }^{3} \mathrm{H}\right]$ thymidine incorporation into UMR 108 osteosarcoma cells (ㅁ), fetal rat calvarial osteoblasts ( $\mathbb{0}$ ), and fetal rat skin fibroblasts ( $\square$ ). Mitogenic activity was expressed as described in the legend to Fig. 1. Control levels of $\left[{ }^{3} \mathrm{H}\right]$ thymidine incorporation into osteosarcoma cells, osteoblasts, and fibroblasts were $28,146 \pm 1,021$, $11,121 \pm 633$ and $10,815 \pm 920 \mathrm{cpm}$, (mean \pm SEM of triplicate determinations), respectively. The column was eluted with a linear gradient $(---)$ of acetonitrile $(A C N)$ containing $0.1 \% \mathrm{~F}_{3} \mathrm{CCOOH}$, as described in the text.

mary culture and a second an established malignant cell line, to examine selective activity relative to that in skin fibroblasts. We have found in this way that two mitogens for osteoblastlike cells may be obtained from hyperplastic tissue with estimated 10,000 and $13,000 \mathrm{~mol} \mathrm{wt}$, whereas a single mitogen for osteoblastlike cells with an apparent $10,000 \mathrm{~mol}$ wt was extractable from prostatic adenocarcinoma. Whether these two

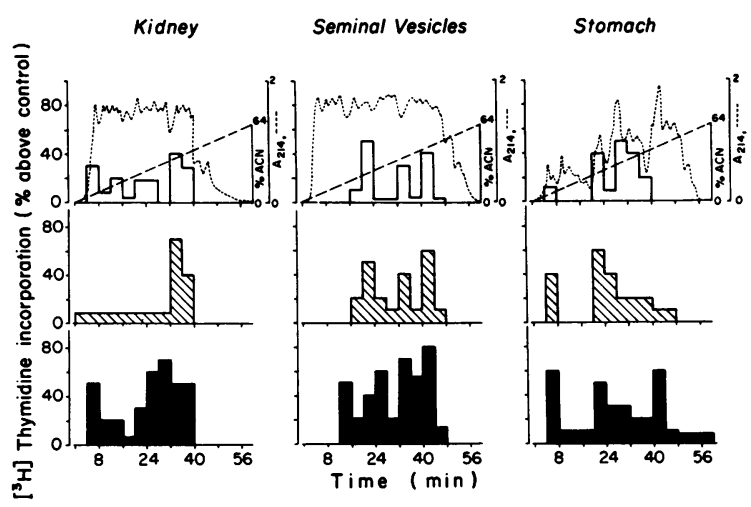

Figure 10. Reverse-phase HPLC profiles of ODS-silica extracts of kidney, seminal vesicles, and stomach. The $\mathrm{C}_{18} \mu$ Bondpak columns were monitored for UV absorbance (- - ) and for bioactivity in assays measuring $\left[{ }^{3} \mathrm{H}\right]$ thymidine incorporation into UMR 108 osteosarcoma cells ( $\square$ ) into fetal rat calvarial osteoblasts ( $\square$ ), and into fetal rat skin fibroblasts ( $\square$ ). Mitogenic activity was expressed as described in the legend to Fig. 1. Control levels of $\left[{ }^{3} \mathrm{H}\right]$ thymidine incorporation into osteosarcoma cells, osteoblasts, and fibroblasts were

$28,146 \pm 1,021,11,121 \pm 633$ and $10,815 \pm 920 \mathrm{cpm}$ (mean $\pm S E M$ of triplicate determinations), respectively. The column was eluted with a linear gradient (- - ) of acetonitrile $(A C N)$ containing $0.1 \%$ $\mathrm{F}_{3} \mathrm{CCOOH}$, as described in the text. 


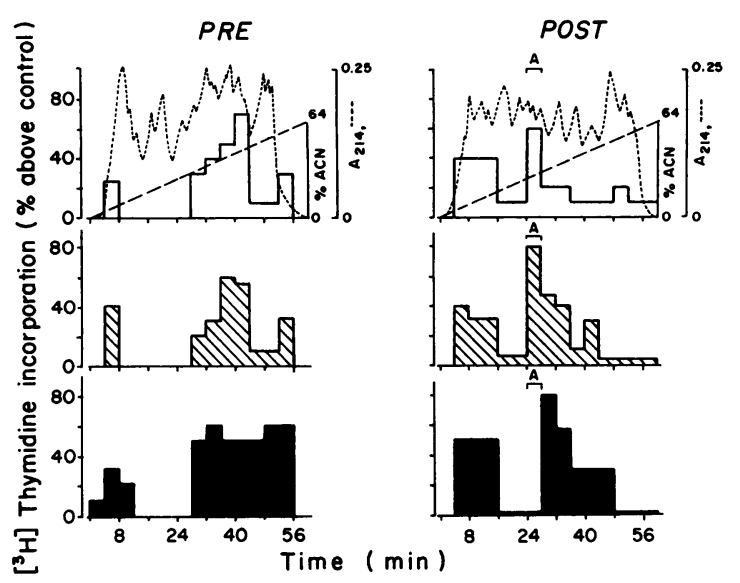

Figure 11. Reverse-phase HPLC profiles of ODS-silica extracts of prepubertal (PRE) and postpubertal (POST) specimens of normal prostatic tissue. The $\mathrm{C}_{18} \mu$ Bondapak column was monitored for UV absorbance and for bioactivity in assays measuring $\left[{ }^{3} \mathrm{H}\right]$ thymidine incorporation into UMR 108 osteosarcoma cells (), fetal rat calvarial osteoblasts ( $₫$ ), and fetal rat skin fibroblasts ( $\square$ ). Mitogenic activity was expressed, as described in the legend to Fig. 1. Control levels of $\left[{ }^{3} \mathrm{H}\right]$ thymidine incorporation into osteosarcoma cells, osteoblasts, and fibroblasts were $28,146 \pm 1,021,11,121 \pm 633$, and 10,815 \pm 920 $\mathrm{cpm}$ (mean $\pm \mathrm{SEM}$ of triplicate determinations), respectively. The column was eluted with a linear gradient ( $-\longrightarrow$ ) of acetonitrile $(A C N)$ containing $0.1 \mathrm{~F} 3 \mathrm{CCOOH}$, as described in the text.

moieties are related as precursor and product or whether they are distinct entities will require further study.

The mitogens appeared to increase cell proliferation, and at least one parameter of differentiated osteoblast function (alkaline phosphatase activity) was enhanced. Although growth factors generally do not employ the adenylate cyclase system for signal transduction, endocrine trophic factors such as thyroid-stimulating hormone are known to stimulate cyclic AMP in target tissues in addition to their effects on enhancing cell growth and differentiated function (15). No significant increase in adenylate cyclase activity was seen in osteoblastlike cells in response to our prostatic mitogens, suggesting that our material does not employ this mechanism of action. This property also distinguishes our material from other peptides, produced by neoplastic tissue and capable of influencing osteoblastic activity, which stimulate adenylate cyclase and have been associated with a hypercalcemic bone-resorbing syndrome.

An increasing number of growth factors have been identified in recent years $(16,17)$ and many may be synthesized by multiple tissues. Consequently, the presence of mitogens in extracts of a variety of neoplastic and normal tissues we examined was not an unexpected finding. Yet, most known growth factors fail to act selectively in the three mesodermal cell types we employed. This and other characteristics, such as apparent molecular weight, also appears to distinguish our human prostatic materials from the acidic prostate-derived growth factor for fibroblasts isolated from rat tissues (18). Although we were unable to identify selective osteoblastlike mitogenic activity in prepubertal prostate, such activity was demonstrable in normal postpubertal tissue, suggesting the possibility of androgen dependence. In view of the higher skeletal mass in males relative to females and the acceleration of skeletal loss after menopause in females, a phenomenon without parallel in the male, the presence of androgen-dependent osseous growth factors in the male could be of major importance in understanding the mechanisms of several basic observations in skeletal physiology.

\section{Acknowledgments}

We thank Mrs. Diane Allen and Vicki Armstrong for excellent secretarial assistance.

This research was supported by Public Health Service grant CA37126 awarded by the National Cancer Institute, grant MT-5775 from the Medical Research Council of Canada, fellowship awards to Dr. Koutilieris and Dr. Rabbani from the Medical Research Council of Canada, and a Scientist Award to Dr. Goltzman from The Medical Research Council of Canada.

\section{References}

1. Jacobs, S. C., D. Pikna, and R. K. Lawson. 1979. Prostatic osteoblastic factor. Invest. Urol. 17:195-198.

2. Jacobs, S. C., and R. K. Lawson. 1980. Mitogenic factor in human prostate extracts. Urology. 16:488-491.

3. Koutsilieris, M., S. A. Rabbani, and D. Goltzman. 1986. Selective osteoblast mitogens can be extracted from prostatic tissue. Prostate. 9:109-115.

4. Simpson, E., J. Harrod, G. Eilon, J. W. Jacobs, and G. R. Mundy. 1985. Identification of a messenger ribonucleic acid fraction in human prostatic cancer cells coding for a novel osteoblast-stimulating factor. Endocrinology. 117:1615-1620.

5. Stewart, A. F., R. Horst, L. J. Deftos, E. C. Cadman, R. Lang, and A. E. Broadus. 1980. Biochemical evaluation of patients with cancer-associated hypercalcemia: evidence for humoral and nonhumoral groups. N. Engl. J. Med. 303:1377-1386.

6. Rice, B. F., R. L. Ponthier, and M. C. Miller. 1971. Hypercalcemia and neoplasia: a model system. Endocrinology. 88:1210-1217.

7. Bennett, H. P. J., S. Solomon, and D. Goltzman. 1981. Isolation and analysis of human parathyrin in parathyroid tissue and plasma: use of reversed-phase liquid chromatography. Biochem. J. 197:391400.

8. Rabbani, S. A., J. Mitchell, D. R. Roy, R. Kremer, H. P. J. Bennett, and D. Goltzman. 1986. Purification of peptides with parathyroid hormonelike bioactivity from human and rat malignancies associated with hypercalcemia. Endocrinology. 118:1200-1210.

9. Peck, W. A., S. J. Birge, Jr., and S. A. Fedak. 1964. Bone cells: biochemical and biological studies after enzymatic isolation. Science (Wash. DC). 146:1476-1477.

10. Yagiela, J. A., and D. M. Woodbury. 1977. Enzymatic isolation of osteoblasts from fetal rat calvaria. Anat. Rec. 188:287-305.

11. Ng, K. W., N. C. Partridge, M. Niall, and T. J. Martin. 1983. Epidermal growth factor receptors in clonal lines of a rat osteogenic sarcoma and in osteoblast-rich rat bone cells. Calcif. Tissue Int. 35:298-303.

12. Majeska, R. J., S. B. Rodan, and G. A. Rodan. 1980. Parathyroid hormone responsive clonal cell lines from rat osteosarcoma. Endocrinology. 107:1494-1503.

13. Demay, M., J. Mitchell, and D. Goltzman. 1985. Comparison of renal and osseous binding of parathyroid hormone and hormonal fragments. Am. J. Physiol. 249:E437-E446.

14. Salomon, Y., C. Landos, and M. Rodbell. 1974. A highly sensitive adenylate cyclase assay. Anal. Biochem. 58:541-548.

15. Dere, W. H., and B. Rapoport. 1986. Control of growth in cultured rat thyroid cells. Mol. Cell. Endocrinol. 44:195-202.

16. James, R. 1984. Polypeptide growth factors. Annu. Rev. Biochem. 53:259-292.

17. Centrella, M., and E. Canalis. 1985. Local regulators of skeletal growth: a perspective. Endocr. Rev. 6:544-551.

18. Machama S., D. Li, H. Narri, J. F. Leykam, and T. F. Deuel. 1986. Purification and partial characterization of prostate-derived growth factor. Proc. Natl. Acad. Sci. USA. 83:8162-8166. 